blessing. For the remainder, doctors should consider the herd immunity that evidently accrues in homes with high immunisation rates ${ }^{21}$ and then wrestle with their consciences.

K G NICHOLSON

Senior Lecturer in Infectious Diseases,

Groby Road Hospital,

Leicester LE3 9QE

1 Department of Health, Welsh Office, Scottish Home and Health Department. Influenza. Immunisation against infectious disease. London: HMSO, 1990:90-5.

2 Bull GM, Morton J. Relationships of temperature with death rates from all causes and from certain respiratory and arteriosclerotic diseases in different age groups. Age Ageing 1975;4:232-46.

3 Bull GM, Morton J. Environment, temperature and death rates. Age Ageing 1978;7:210-24.

4 Alderson MR. Season and mortality. Health Trends 1985;17:86-96.

5 Communicable Disease Surveillance Centre. Respiratory syncitial virus infection in the elderly, 1976-1982. Br Med f 1983;287:1618-9.

6 Nicholson KG, Baker DJ, Farquhar A, Hurd D, Kent J, Smith SH. Acute upper respiratory tract illness and influenza immunisation in homes for the elderly. Epidemiol Infect (in press).

7 Immunization Practices Advisory Committee. Prevention and control of influenza. MMWR 1987;36:373-80

8 Tillett HE, Smith JWG, Gooch CD. Excess deaths attributable to influenza in England and Wales: age at death and certified cause. Int $f$ Epidemiol 1983;12:344-56.
9 Chakraverty P, Cunningham P, Shen GZ, Pereira MS. Influenza in the United Kingdom 1982-85. fournal of Hygiene (Cambridge) 1986;97:347-58.

10 Curwen M, Dunnell K, Ashley J. Hidden influenza deaths. Br Med $\mathcal{F}$ 1990;300:896.

11 Barker WH, Mullooly JP. Pneumonia and influenza deaths during epidemics. Arch Intern Med 1982;142:85-9.

12 Arden NH, Patriarca PA, Kendal AP. Experiences in the use and efficacy of inactivated influenza vaccine in nursing homes. In: Kendall AP, Patriarca PA, eds. Options for the control of influenza. New York: AR Liss, 1986:155-68.

13 Feery J, Evered MG, Morison El. Different protection rates in various groups of volunteers given sub-unit influenza virus vaccine in 1976. F Infect Dis 1979;139:237-41

14 Howells $\mathrm{CHL}$, Vesselinova-Jenkins $\mathrm{CK}$, Evans $\mathrm{AD}$, James J. Influenza vaccination and mortality from bronchopneumonia in the elderly. Lancet 1975;i:381-3.

15 Serie C, Barme M, Hannoun C, Thibon M, Beck H, Aquino JP. Effects of vaccination on an influenza epidemic in a geriatric hospital. Dev Biol Stand 1977;39:317-21.

16 Patriarca PA, Weber JA, Parker RA, el al. Efficacy of influenza vaccine in nursing homes. FAMA 1985;253:1136-9.

17 Gross PA, Quinnan GV, Rodsein M, et al. Association of influenza immunization with reduction in an elderly population. Arch Intern Med 1988;148:562-5.

18 Barker WH, Mulloly JP. Influenza vaccination of elderly persons:.reduction in pneumonia and influenza hospitalizations and deaths. FAMA 1980;244:2547-9.

19 Nicholson KG, Wiselka MJ, May A. Influenza vaccination of the elderly: perceptions and policies of general practitioners and outcome of the 1985-86 immunization programme in Trent, UK. Vaccine 1985;5:302-6.

20 Lennox IM, Macphee GJA, McAlpine CH, Cameron SO, Leask BGS, Somerville RG. Use of influenza vaccine in long-stay geriatric units. Age Ageing 1990;19:169-72.

21 Patriarca PA, Weber JA, Parker RA, et al. Risk factors for outbreaks of influenza in nursing homes: a case control study. Am f Epidemiol 1986;124:114-9.

\title{
Vasectomy and the human testis
}

\section{We still know too little about the effects of vasectomy}

Concerns about vasectomy have so far focused on its reversibility ${ }^{1-3}$ and fears that it might predispose to cardiovascular disease. ${ }^{45}$ But a recent study by Cale $e t a l$ has raised a new and serious worry: that vasectomy might accelerate the growth of testicular tumours. ${ }^{6}$

Of a cohort of over 3000 men in central Scotland who had undergone vasectomy, eight developed testicular cancer within four years after the operation-compared with an expected $1 \cdot 9 .^{6}$ As the authors did not indicate the types of tumours we do not know whether this finding was just an unhappy coincidence (as different tumour types would suggest) or whether we should be more worried (as similar pathological appearances would suggest).

This is not the first suspicion of accelerated testicular tumour growth after vasectomy. Thornhill et al in Dublin reported three cases of a comparatively rare mixed seminoma and malignant teratoma within eight weeks after surgery. Strader et al reported an increased incidence of testicular cancer among Catholic but not among non-Catholic men in Washington state ${ }^{8}$ but they attributed the difference to a failure to report vasectomy by Catholic controls in the questionnaire study.

These observations may be chance findings by rightly cautious practitioners, and there is insufficient evidence to implicate vasectomy in accelerated tumour growth. If vasectomy does promote such growth it is not clear how it does so. Indeed, its general effects on the human testis are controversial and incompletely understood.

Animal studies have made it clear that there are considerable differences in the effects of vasectomy among species. Dogs show temporary depression of spermatogenesis, which may be related to raised intraluminal pressure ${ }^{9-12}$; guinea pigs suffer autoimmune orchitis with infiltration by leukocytes $^{13}$; rabbits develop degeneration of the seminiferous epithelium associated with deposition of immune complexes along the basement membrane ${ }^{1+15}$; and rats, rabbits, and hamsters all show testicular atrophy associated with the formation of sperm granulomas in the caput epididymidis. ${ }^{16-18}$
Which, if any, of these models applies to man is not known.

Several groups have reported finding abnormalities in testicular biopsy specimens in some men after vasectomy. ${ }^{19-25}$ The changes are variable but include degeneration of seminiferous epithelium; loss of germ cells, especially spermatids; dilatation of testicular tubules; thickening of tubular walls; and interstitial fibrosis. The causes are not known. Dilatation of seminiferous tubules suggests raised intraluminal pressure ${ }^{2425}$ which might account for the epithelial changes. Raised intraluminal pressure has been detected in the seminiferous tubules of guinea pigs given vasectomies. ${ }^{26}$ Rats with vasectomies, although usually showing normal testes, ${ }^{27}$ develop appreciable distension of seminiferous tubules if the caput epididymidis becomes obstructed..$^{17} 18$

Some of these changes may be reversible. Three groups of workers have shown that some men who undergo reversal of vasectomy are subsequently fertile despite showing pronounced degeneration on testicular biopsy at the time of reversal. ${ }^{22} 24$ In dogs the depression of spermatogenesis after vasectomy is only temporary and may be attributable to raised intraluminal pressure. ${ }^{9-12}$ Perhaps the seminiferous epithelium of the dog adapts more readily to raised pressure than that of man and regressive changes in humans are reversed only when the ductus deferens is reanastomosed. The presence of interstitial fibrosis in biopsy specimens taken at the reversal of vasectomy may carry a poor prognosis for fertility. ${ }^{24}$

Bigazzi and Alexander and Tung, working on rabbits with vasectomies, reported degeneration of seminiferous epithelium associated with immune complex deposition in the basement membrane; elution techniques showed that the complexes contained antisperm antibodies. ${ }^{1+15}$ Because just under two thirds of men who have undergone vasectomy develop serum antisperm antibodies ${ }^{28}{ }^{29}$ it has been suggested that the thickening of the tubular walls seen in testicular biopsy specimens from such patients may represent the same process, but Bigazzi et al could not show any immune complex deposition. $^{23}$ 
Several groups have attempted to investigate the effect of vasectomy on the endocrine function of the human testis..$^{30-37}$ The results have been conflicting and difficult to interpret because the changes may have been due to alterations in the sensitivity of the assay. ${ }^{35}$ Nevertheless, it does seem that hormone concentrations remain within the normal range after vasectomy, though seasonal variations seem to be lost. ${ }^{38}$

Clearly, then, we need to learn much more about the effect of vasectomy on seminiferous tubules. We need to know about the possibility of different forms of testicular change in different people, predisposing factors such as a history of orchitis or a personal or family history of autoimmune disease, and the relation between the formation of sperm granulomas and testicular changes in man. Most importantly, however, we need further studies to define the risk of testicular cancer after vasectomy and to identify causal factors.

Lecturer in Anatomy,

University of Glasgow,

Glasgow G12 8QQ

STUART W MCDONALD

1 Silber SJ. Vasectomy and vasectomy reversal. Fertil Steril 1978;29:125-40.

2 Linnet L, Hjort T, Fogh-Anderson P. Association between failure to impregnate after vasovasostomy and spermagglutinins in semen. Lancet 1981;i:117-9.

3 Fuchs EF, Alexander NJ. Immunologic considerations before and after vasovasostomy. Fertil Steril 1983;40:497-9.

4 Clarkson TB, Alexander NJ. Long-term vasectomy: effects on the occurrence and extent of atherosclerosis in the rhesus monkey. $\mathcal{F}$ Clin Invest 1980;65:15-25.

5 Campbell WB. Vasectomy and arterial disease. $\mathcal{F} R$ Soc Med 1988;81:683-5.

6 Cale ARJ, Farouk M, Prescot RJ, Wallace IWJ. Does vasectomy accelerate testicular tumour? Importance of testicular examinations before and after vasectomy. Br Med f 1990;300:370.

7 Thornhill JA, Butler M, Fitzpatrick JM. Could vasectomy accelerate testicular cancer? The importance of prevasectomy examination. Brf Urol 1987;59:367.

8 Strader $\mathrm{CH}$, Weiss NS, Daling JR. Vasectomy and the incidence of testicular cancer Am $\mathcal{F}$ Epidemiol 1988;128:56-63.

9 Grewal RS, Sachan MS. Changes in testicle after vasectomy. An experimental study. Int Surg 1968;49:460-2.

10 Kothari LK, Mishra P, Mishra RK. Effect of bilateral vasectomy on the structure and function of the testis. Am $\mathcal{F}$ Surg 1973;126:84-8.

11 MacDougall MK, McCowin K, Derrick FK, Glover WL, Jacobson CB. The effects of vasectomy on spermatogenesis in the dog, Canis familiaris: a meiotic analysis. Fertil Steril 1975;26:786-90.

12 Vare AM, Bansal PC. Changes in the canine testis after bilateral vasectomy-an experimental study. Fertil Steril 1973;24:793-7.

13 Tung KSK. Pathogenesis of testicular pathology in vasectomized guinea pigs. In: Lepow IH, Crozier R, eds. Vasectomy: immunologic and pathophysiologic effects in animals and man. New York: Academic Press, 1979:407-21.
14 Bigazzi PE. Immunopathological findings in vasectomized rabbits. In: Lepow IH, Crozier R, eds Vasectomy: immunologic and pathophysiologic effects in animals and man. New York: Academic Press, 1979:339-53.

15 Alexander NJ, Tung KSK. Vasectomy in the rabbit: immunological and morphological effects. In: Lepow IH, Crozier R, eds. Vasectomy: immunologic and pathophysiologic effects in animals and man. New York: Academic Press, 1979:355-77.

16 Bedford JM. Adaptations of the male reproductive tract and the fate of spermatozoa following vasectomy in the rabbit, rhesus monkey, hamster and rat. Biol Reprod 1976;14:118-42.

17 McDonald SW, Falconer JS, Al-Saffar RA, Scothorne RJ. Sperm granuloma formation in the caput epididymidis is associated with testicular degeneration in rats. Clinical Anatomy 1990;3:65.

18 McDonald SW, Spilg EG, Alexander JA, Scothorne RJ. Testicular atrophy following vasectomyis the position of the sperm granuloma important? Clinical Anatomy 1990;3:68.

19 Derrick FC, Glover WL, Kanjuparamban Z, et al. Histological changes in the seminiferous tubules after vasectomy. Fertil Steril 1974;25:649-58.

20 Gupta AS, Kothari LK, Dhruva A, Bapna R. Surgical sterilization by vasectomy and its effect on structure and function of the testis in man. Brf Surg 1975;62:59-63.

21 Fallon $\mathrm{F}$, Jacobo L, Bunge RE. Restoration of fertility by vasovasostomy. $f$ Urol 1978;119:85-6.

22 Jenkins JP, Muir VY, Blacklock NJ, Turk JL, Hanley HG. Consequences of vasectomy: an immunological and histological study related to subsequent fertility. Brf Urol 1979;51:406-10.

23 Bigazzi PE, Alexander NJ, Silber SS. Studies on testicular biopsies from vasectomized men. In: Lepow IH, Crozier R, eds. Vasectomy: immunologic and pathophysiologic effects in animals and man. New York: Academic Press, 1979:459-69.

24 Jarow JP, Budin RE, Dym M, Zirken BR, Noren S, Marshall FF. Quantitative pathologic changes in the human testis after vasectomy. A controlled study. $N$ Engl $\mathcal{F}$ Med 1985;313:1252-6.

25 Mehrotra $\mathrm{R}, \mathrm{Nath} \mathrm{P}$, Singh $\mathrm{KM}$, et al. Changes in seminiferous tubules after vasectomy. Indian $\mathcal{f}$ Pathol Microbiol 1985;28:371-8.

26 Howards SS, Johnson AL. Effects of vasectomy on intratubular hydrostatic pressure in the testis and epididymis. In: Lepow IH, Crozier R, eds. Vasectomy: immunologic and pathophysiologic effects in animals and man. New York: Academic Press, 1979:55-67.

27 McDonald SW, Scothorne RJ. A quantitative study of the effects of vasectomy on spermatogenesis in rats. $\mathcal{F}$ Anat 1988; 159:219-25.

28 Samuel T, Kolk AHJ, Rumke P, Van Lis JMJ. Autoimmunity to sperm antigens in vasectomized men. Clin Exp Immunol 1975;21:65-74.

29 Ansbacher R, Hodge P, Williams A, Mumford DM. Vas ligation, humoral sperm antibodies. Int f Fertil 1976;21:258-60.

30 Rosemberg E, Marks SC, Howard PJ, James LP. Serum levels of follicle stimulating and luteinizing hormones before and after vasectomy in men. $\mathcal{F}$ Urol 1974;111:626-9.

31 Kobrinsky NL, Winter JSD, Reyes FI, Fairman C. Endocrine effects of vasectomy in men. Fertil Steril 1976;27:152-6.

32 Naik VK, Thakur AN, Sheth AR, et al. The effect of vasectomy on pituitary-gonadal function in men. I Reprod Fertil 1976;48:441-2.

33 Smith KD, Tcholakian RK, Chowdhury M, Hsi BP. Endocrine studies in vasectomized men. In: Lepow IH, Crozier R, eds. Vasectomy: immunologic and pathophysiologic effects in animals and man. New York: Academic Press, 1979:183-200.

34 Whitby RM, Gordon RD, Blair BR. The endocrine effects of vasectomy: a prospective five-year study. Fertil Steril 1979;31:518-20.

35 Goebelsmann U, Bernstein GS, Gale JA, et al. Serum gonadotrophin, testosterone, estradiol, and estrone levels prior to and following bilateral vasectomy. In: Lepow IH, Crozier R, eds. Vasectomy: immunologic and pathophysiologic effects in animals and man. New York: Academic Press, 1979:165-81.

36 Varma MM, Varma RR, Johanson AJ, Kowarski A, Migeon CJ. Long-term effects of vasectomy on pituitary-gonadal function in man. $\mathcal{F}$ Clin Endocrinol Metab 1975;40:868-71.

37 Skegg DCG, Mathews JD, Guillebaud J, et al. Hormonal assessment before and after vasectomy. BrMed F 1976;i:621-2.

38 Reinberg A, Smith KD, Smolensky MH, Steinberger E, Hallek M. Annual variation in semen characteristics and plasma hormone levels in men undergoing vasectomy. Fertil Steril 1988;49:
$309-15$.

\section{Hirsutism}

\section{Treatable and usually caused by the polycystic ovary syndrome}

In the past decade the polycystic ovary has emerged clearly as the source of excess androgens in most hirsute women, ${ }^{1}$ and the establishment of effective antiandrogen treatment, combining oestrogen with cyproterone acetate, ${ }^{2}$ has resulted in an increased demand for treatment by patients and doctors. We now enter an era in which the long term safety of treatment must be determined to provide a more accurate assessment of the risk-benefit ratio of hormone treatment.

Until recently most patients with excess hair growth were labelled as having idiopathic hirsutism because they had no discernible abnormality of the menstrual cycle or of gonadotrophin or androgen secretion. Two lines of investigation have altered our understanding of the pathogenesis of hirsutism. Firstly, the total serum testosterone concentration, which is normal in many hirsute patients, has been shown to be an inaccurate reflection of androgen production. More subtle investigation has shown that excess androgen concentrations exist in nearly all patients. ${ }^{3-5}$ Moreover, specific venous sampling has shown the ovary rather than the adrenal gland to be the source of androgen excess. ${ }^{6}$ Secondly, ultrasonographic examination of the ovary has shown the typical morphology of the polycystic ovary in $92 \%$ of women with hirsutism. ${ }^{7}$ Most hirsute women have symptomatic and biochemical hyperandrogenism together with polycystic ovaries. Hirsutism is therefore one of the components of the polycystic ovary syndrome, even when the menstrual cycles and gonadotrophin concentrations are normal.

Many investigators have been tempted by the notion of a single mechanism to explain hyperandrogenism, but it is probably the result of defects in several metabolic and endocrine pathways. Induction of excessive synthesis of ovarian androgens through stimulation by luteinising hormone, ${ }^{89}$ insulin, ${ }^{910}$ or corticotrophin ${ }^{11}$ or through overactivity of the cytochrome $P-450$ c17 $\alpha$ enzyme complex ${ }^{12}$ have all been postulated. Applying molecular techniques to the study of hormone production should define subgroups of women with 